\title{
Teaching Empathy through Movies: Reaching Learners' Affective Domain in Medical Education
}

\author{
Pablo González Blasco ${ }^{1} \&$ Graziela Moreto ${ }^{1}$ \\ ${ }^{1}$ SOBRAMFA-Brazilian Society of Family Medicine, São Paulo, Brazil \\ Correspondence: Pablo González Blasco, SOBRAMFA-Brazilian Society of Family Medicine, Rua Silvia, 56. \\ 01331-010, São Paulo, Brazil. E-mail: pablogb@sobramfa.com.br
}

Received: April 11, 2012

Accepted: April 24, $2012 \quad$ Published: June 1, 2012

doi:10.5539/jel.v1n1p22

URL: http://dx.doi.org/10.5539/jel.v1n1p22

\begin{abstract}
We live in an era where outcomes, guidelines, and clinical trials are at the forefront of medical training. However, to care implies having an understanding of the human being and build reflective practitioners impregnated of a humanistic perspective of doctoring. Although technical knowledge and skills can be acquired through training with little reflective process, it is impossible to refine attitudes, acquire virtues, and incorporate values without reflection. Empathy, which is required for a deep understanding of the human condition, could bridge the gap between patient-centered medicine and evidence-based medicine therefore representing a profound therapeutic potential. The challenge is how to teach empathy, an important issue in medical education, hard to teach and to measure. The authors' broad experience in medical education using movies points out an innovative methodology to promote empathy because it reaches the learners' affective domain. A description of the cinematic teaching methodology is provided and an extensive list of movie scenes are included so faculty and educators can try it in their own teaching scenario.
\end{abstract}

Keywords: cinema and education, empathy, medical education, affective education, learning through emotions

\section{Educating Emotions: Bridging Technology with Humanism}

We live in an era where outcomes, guidelines, and clinical trials are at the forefront of medical training. However, to care implies having an understanding of the human being and the human condition and for this endeavor, humanities and arts help in building a humanistic perspective of doctoring. Through these means, doctors are able to understand patients in their whole context. The humanities and arts provide a source of insight and understanding for proper doctoring and, as such, they should be as much a part of medical education as training in differential diagnosis or medical decision-making. Teaching how to effectively take care of people requires creating educational methods that address the human aspects of medicine.

Because people's emotions play a specific role in learning attitudes and behavior, educators cannot afford to ignore students' affective domain. Although technical knowledge and skills can be acquired through training with little reflective process, it is impossible to refine attitudes, acquire virtues, and incorporate values without reflection. The challenge here is to understand how to effectively provoke students' reflective process.

Learning through aesthetics -in which cinema is included-stimulates a reflective attitude in the learner. The first step in humanizing medical education is to keep in mind that students are reflective beings who need an environment that supports and encourages this activity. Because emotions and images are ubiquitous in popular culture, they should be the front door in students' learning process about feelings. In fact, when systematically incorporated into the educational process, and allowed to flow freely in the educational setting, emotions make learning both more memorable and more pleasurable for students.

Complexity comes mostly from patients, not from diseases. While technical knowledge helps in solving disease-based problems, the patient affected by these diseases remains a real challenge for the practicing doctor. To care implies having an understanding of the human being. Arts and humanities, because they enhance the understanding of the human condition, are useful resources when incorporated into the educational process and help in building a humanistic perspective of doctoring (Blasco, 2001).

\section{The Soft Edges of Empathy}

Empathy, from the Greek empatheia, means understanding someone else's feelings. In the English vocabulary 
empathy was used initially to describe the observers' feeling when interfacing with artistic expression. Afterwards, the term was related to understanding people, and in 1918, Southard incorporate the word empathy into the doctor-patient relationship, as a resource for facilitating diagnosis and therapeutics (Hojat, 2007).

Whether empathy is mainly an affective condition, or a cognitive one, or both, is a broad discussion which bring us to another dilemma, an educational issue: could empathy be taught or is it a trace of personality?

The majority of the authors with an affective oriented approach presuppose that, during the empathic event, there is something that can be characterized as a partial identification of the observer with the observed. This aspect also becomes clear especially in Carl Rogers' definition, which describes empathy as being the ability "to sense the client's private world as if it were your own, but without losing the 'as if' quality". According to this definition, the differentiation between one's own experience and the experience of another is the decisive criterion for defining effective empathy (Neumann et al., 2009).

Other authors (Stephan \& Finlay, 1999) stress the importance of making a distinction between sympathy and empathy, in particular, arguing that such a distinction has significant implications for the relationship between patients and clinicians because joining with the patient's emotions can impede clinical outcomes. Moreover, a clinician who is merely sympathetic in the clinical encounter can interfere with clinical objectivity and professional effectiveness. The sympathetic doctor cares about quantity and intensity of patient's suffering, while the empathetic doctor cares about understanding the quality of patient's experience (Hojat et al., 2009). These authors' general conclusion is, therefore, that sympathy must be restrained in clinical situations, whereas empathy does not require a restrictive boundary (Hojat, Gonnella, Mangione, Nasca \& Magee, 2003).

It is not easy to separate in practice (herein meaning in action) the affective from the cognitive domain. Thus, some other authors explain that empathy, rather than continuing to focus on "feeling into" the experiences of another, has more to do with the understanding of the other's feelings than the sharing of them (Kohler, 1929). Following the "symbolic interactionism" and Piaget's theory of cognitive development (Piaget, 19320) Mead articulates the term "role taking", a process of understanding and anticipating the actions and reactions of another individual. Role-playing implies that an individual produces the perspectives of another person within himself: "The immediate effect of such role taking lies in the control which the individual is able to exercise over his own response. It is the ability of the person to put himself in other people's places that gives him his cues as to what he is to do in a given situation". (Mead, 1934).

Two conclusions might be drawn from our discussion of definitions and our questions regarding the right location (affective, cognitive or both) in which empathy occurs. First is that a prerequisite for both affective and cognitive empathy is that an individual should not be overly preoccupied with himself and his own concerns, because, if the experience is to a greater extent focused on the individual himself, then the willingness to help the other person decreases (Aderman \& Berkowitz, 1983). Only through self-awareness is it possible to see the behavior of the observed person as an expression of his emotional state and to make a mental distinction between oneself and the "other self". The second conclusion is that empathy could bridge the provide gap between patient-centered medicine and evidence-based medicine therefore representing a profound therapeutic potential.

And here we come to the educational issue. Can empathy be taught? Is it possible to establish a learning process for empathy?

\section{Teaching the Non-teachable Issues}

A classic study published twenty five year ago comes to mind (Sade, Stroud, Levine \& Fleming, 1985). This study was mainly designed to help medical school admission committees to better select college students for medical school. The authors of the study emphasized that it is probably more important to select college students who will be superior physicians than to select those who will be excellent medical students. Based on a previously publication, subjects were asked to rank order list of 87 characteristics of a superior physician considering the importance of each characteristic and how easily it could be taught. Those ratings were validated by high correlations across several subgroups. The importance and the teachability ratings were combined into a nonteachable-important index (NTII) that provides a rank order of traits that are important but cannot be taught easily.

This study aimed to determinate the important qualities of a superior physician that cannot easily be taught in medical school or later training. The authors proposed to select college students for medical school not only on the basis of academic achievement, but also on the basis of characteristics identifiable in the college student that predict excellence in the physician who many years later will emerge from our educational system.

The NTII generated by this study gives equal weight to importance and to nonteachability. The top of the list 
comprises qualities closely related to empathy: understanding people, sustaining genuine concern for patients, motivated primarily by idealism, compassion and service; oriented more toward helping people than making income; enthusiasm for medicine and dedication to his work, ability to get the heart of a problem and to separate important points from details and adaptability. All those qualities score high in the NTTI index, which means: very important, and difficult to teach. This is the real challenge for teaching empathy.

Some neurophysiological studies bring certain clues (Decety \& Jackson, 2006) (Gallese, 2003) to solve the dilemma of how to teach something that is difficult to teach. Even though empathy is a non traditional teaching content, it might be promoted through examples and role taking through which the neurophysiological indicators of empathy could be activated. There are some neurons in the brain which can control certain actions (e.g., behavior or emotion) in the body and can even be activated if the same action is observed in another person. Known as mirror neurons, these nerve cells respond spontaneously, involuntarily and even without thinking (Rizzolatti \& Sinigaglia, 2006). Mirror neurons use the neurobiological inventory of the observer in order to make him feel what is taking place in the person that he/she is observing by way of inner simulation. Various experiments conducted by the so-called "social neurosciences" document the functioning of the mirror neurons with regard to the empathic perception of the other person (Decety \& Jackson, 2004) (Wicker et al., 2003). The functioning of mirror neurons is, therefore, an essential prerequisite for empathy (Bauer, 2005).

Nevertheless, another question rises up in this mirroring role model theory: is a subsequently learned empathic ability authentic or does it gives a patient the impression that it is an artificial and superficial behavior (i.e., a routine checklist of empathic actions that a clinician is simply required to go through)? Do clinicians need to have previous experience being patients themselves or to witness their family/friends being patients in order to be more empathic? These questions can have great implications for medical education and medical care considering that empathy seems to be a determinant of quality in medical care because it enables the clinician to fulfill key medical tasks more accurately, thereby leading to enhanced health outcomes.

Those who are involved in medical education know that a broad range of biographical experiences and situational factors influence the development and promotion of empathy. Part of these experiences could be the role model teaching scenario, in which students and young doctors are inspired by the teacher's attitudes in dealing with patients. The Tag-along model allows medical students to incorporate attitudes, behaviors, and approaches to real patients and identify emerging issues useful for their professional future (Blasco, Roncoletta, Moreto, Levites \& Janaudis, 2006).

Beside Tag-alongs, some authors emphasize the importance of art, literature, cinema and reflecting over one's own life in developing empathy (Larson \& Yao, 2005). Literature has plenty of examples, and choosing appropriately is always a dilemma. In A Fortunate Man (Berger \& Mohr, 1967), a classic book about the story of a country doctor, there is a broad description of empathy, here called Recognition. "The task of the doctor is to recognize the man. (..) I am fully aware that I am here using the word Recognition to cover whole complicated techniques of psychotherapy, but essentially these techniques are precisely means for furthering the process of recognition. (..) In order to treat the illness fully, the doctor must first recognize the patient as a person. Good general diagnosticians are rare, not because most doctors lack medical knowledge, but because most are incapable of taking in all the possible relevant facts -emotional, historical, environmental as well as physical. They are searching for specific conditions instead of the truth about a patient which may then suggest various conditions. (..) A good doctor is acknowledged because he meets the deep but unformulated expectation of the sick for a sense of fraternity. He recognizes them. Sometimes he fails, but there is about him the constant will of a man trying to recognize".

Cinema, as well, is capable of portraying a tremendous spectrum of what empathy is about. And this is our next topic.

\section{Using Movies to Foster Reflection: Summarizing a Twelve Years Educational Experience}

As the audiovisual resources are omnipresent in our current culture, opportunities for teaching with cinema are well suited to the learners' environment. This learning scenario stimulates learner reflection. In life, important attitudes, values, and actions are taught using role modeling, a process that impacts the learner's emotions. Since feelings exist before concepts, the affective path is a critical shortcut to the rational process of learning.

Cinema is useful in teaching because it is familiar and evocative. Movies provide a quick and direct teaching scenario in which specific scenes point out important issues, emotions are presented in accessible ways where they are easy to identify, and learners are able to understand and recognize them immediately. In addition, learners have the opportunity to "translate" movie life histories into their own lives, and into a medical context, even when the movie addresses a non- medical subject. Movie experiences act like emotional memories for 
developing attitudes and keeping them as reflective reference in the daily activities.

Cinema is the audiovisual version of storytelling. Life stories and narratives enhance emotions, and therefore set up the foundation for conveying concepts. Movies provide a narrative model framed in emotions and images that are also grounded in the everyday universe. As in the clinical setting, the patients' life histories are a powerful resource in teaching. When the goal is promoting reflection -including both cognitive and emotional components-, life histories derived from the movies are well- matched with the learners' desires and expectations. (Blasco, 2002) To foster reflection is the main goal in this cinematic teaching set. The purpose is not to show the audience how to incorporate a particular attitude, but rather to promote their reflection and to provide a forum for discussion.

The experiences we have with cinematic teaching span more than a decade (Blasco, 2011 a). Our experience affirms the effectiveness of using the movie-clip methodology in which multiple movie clips are shown in rapid sequence, along with facilitator comments while the clips were going on. Teaching with clips in which several, rapid scenes, taken from different movies are all put together, works better than viewing the whole movie (Blasco, Moreto, Roncoletta, Levites \& Janaudis, 2006). Nowadays, we live in a dynamic and fast paced environment of rapid information acquisition and high emotional impact. In this context it makes sense to use movie clips because of their brevity, rapidity and emotional intensity. Bringing clips from different movies, to illustrate or intensify a particular point fits well with this modern living state.

The value of instructor commentary during the viewing of clips is a conclusion based on our own experience (Blasco, González-Blasco, Levites, Moreto \& Tysinger, 2011). Although the sudden changing of scenes in the clips effectively evoke participants' individual concerns, and fosters reflection in them, making comments while the clip is playing acts as a valuable amplifier to the whole process. Because learners are involved in their personal reflective process, they may at times disagree with the facilitator's comments and form their own conclusions. But this doesn't matter, and may even be desirable. In fact, participants note that divergent comments are particularly useful to facilitate the reflecting process. A quote from one medical student elucidates this point:

"Don't keep quiet, please. You must make your comments while the movie is going on.....Do you ask if I agree with you? No, I don't agree at all....But your comments push me to reflect....so please, go on."

The effect is a rich generation of perspectives and points of view, which in turn trigger multiple, often, contradictory emotions and thoughts in the viewers. In this context, learners' have an intensely felt need for reflection about what they have just seen. American movies are particularly useful, since they tend to tell stories in a straightforward and uncomplicated manner. Although European or Asian movies often stimulate deep meditation on human values, they demand more time and attention on the part of learners.

The last part of the movie clip teaching methodology is the most important and constructive. There may be a temptation on the part of both audience and instructor to feel satisfied with the emotions (and often tears) appearing by the end of the clip. In fact, this is where the real work starts. People need to share, and further consider, their thoughts and feelings in light of the comments and responses of their peers. This final discussion is absolutely necessary to put into coherent perspective the emotions, insights, dreams, and fears that the film clips evoked.

Fostering reflection post-viewing often stimulates conversations about the interaction of health and illness within the breadth of human experience and can elicit profound conflicts and concerns from students about their future professional roles and themselves as human beings. Students identify easily with film characters and movie "realities", and through a reflective attitude gain new insights into many important aspects of life and human relationships. The educational benefit also is expanded by the phenomenon of students' "carrying forward" into their daily lives the insights and emotions initially generated in response to the movie clips. In other words, students report that the movie clip training acts like "an alarm" to make them more aware when similar issues and situations occur in their daily lives (Blasco, Pinheiro, Ulloa-Rodriguez \& Angulo-Calderón, 2009).

Participants understand that the purpose of the film-clip methodology is not only to evoke emotions but to help the audience reflect on these emotions and figure out how to translate what they learn into attitudes and action. Reflection is the necessary bridge to move from emotions to behavior. The goal is to move beyond a specific medical solution to reach a human attitude in life that requires integrity and wholeness. The purpose is to move from technical responses to deep reflection on how to call forth the best learners have inside themselves. The specific translational process is intentionally left up to learners as they encounter their own lives as doctors and as people. 
In our experience, the topics that emerge in these discussions are critical to understanding the human condition. Thus, the importance of dialogue and respect for others' opinions and perspectives, caring about little things in life (which makes difference when dealing with people), promoting compassion, empathy, and commitment are all invaluable.

For teaching the human matters of doctoring, which implies refining attitudes, acquiring virtues, and incorporating values, one can employ the purely rational method favored by ethics lectures and deontology courses. But movies offer another path: exposing learners to particular examples with strong emotional consequences to either follow or reject. The movie clips lead the learners to reflect on where their own attitudes and responses will lead, not only intellectually but emotionally, both for themselves and others. In this way, bringing examination of emotional responses and their consequences into the discussion serves as an effective shortcut that helps reconnect learners with their original idealistic aspirations and motivations as physicians (Blasco et al., 2010).

Emotions are a universal language that help people to bridge cultural differences and achieve agreed upon interpretations and mutual understanding (Blasco, Mônaco, Benedetto, Moreto \& Levites, 2010). At this point, we can envision why those "intangibles" issues, difficult to teach and to assess, in which empathy, compassion and commitment are included, could be endorsed through the cinema education methodology.

\section{Understanding Deeply: Methodology, Outcomes, Appraisal and Limitations}

The broad bibliography offered in the previous topic in which our experience is already published is the best guide to immerse into the cinema teaching methodology. However, some points could be stressed to clarify and help those who want to apply this approach in their teaching setting.

\subsection{Which Movies are Useful for Teaching This or That Point? Why Clips or Just Some Scenes Instead the Whole Movie?}

Those are commons questions readers ask. The answer depends on what you want to point out, the time you have at your disposal, and the outcomes you expect. Anyway, what is really true is that what you get out of a film often depends upon what you bring to it. Useful movies for teaching whatever you want are those that are valuable to you, those that touched you and lead you to reflect. I can share what movies touched me and why, but I am not able to say what will impress you and be part of your life. So you need to build your own experience before sharing with your audience. Keep in mind what you want to teach, the specific ethical dilemma.

\subsection{And How Does It Seem an Educational Session with Using Movie Clips Methodology?}

Usually the session starts with a brief theoretical background, stressing the importance of the teaching points (empathy, patient doctor relationship, etc.). When there is a small group, people introduce their selves at the very beginning and say what expect from the session. Then comes a 20-30 minutes period in which multiple movie clips are shown in rapid sequence, along with some facilitator comments while the clips are going on. The proper methodology in cinematic teaching includes the open discussion after showing the movie clips in which the attendants ask questions and share their reflections, feelings, and thoughts. When the audience is large and session scheduling (2-3 hours) allows it, the facilitator breaks the audience into small groups to encourage discussion. At the end of the session, the large group meets together and spokespersons from the small groups share the topics discussed in their groups.

\subsection{Is All This about Emotions? Is There any Learning and Education or just Affective Reactions with No Further Outcomes?}

It would be incorrect to presume that simply showing a film suffices to teach medical ethics, or that the integration of film could replace thoughtful reading and analysis of essential texts. Movies are the start point to foster reflection in the learners, and without this reflective process-just assigning to the particular scene the teaching responsibility, expecting all the outcomes from the photograms even though illustrated with the correspondent comments- the results might be frustrating. (Colt H, Quadrelli S \& Friedman L, 2011) (Blasco, 2011 b)

Education using film must not stop with the evocation of learners' emotions but further guide learners through discussions with their peers and role models. Such a group process is designed to assist learners in carrying forward their "movie learning" into their daily lives, by addressing the question of how to bridge the gap between the illusion of the movies and the reality of patient care (Shapiro, 2011)

These outcomes could be outlined through some of the quotes coming from the participants in several sessions (Blasco et al., 2010), (Blasco, Mônaco, Benedetto, Moreto \& Levites, 2010). 
"The cinematic experience pushes us to reflect and to not forget what really matters in our life as doctors. We live in a technological world and when we try to know everything about the specific, we might really forget the wholeness, about reality. This works as a tremendous recall for keeping the focus".

"This was a terrific experience to me. That movie, in which the young man decided to live his life despite what their parents want was inspiriting. Yes, we need to make the difference with our lives and so we need to remember who we are and what we really want".

"To my surprise, this teaching method succeeded in keeping the poetry of the clips untouched. While viewing the movie clips, there was less message-dissecting, yet much more stimulation to reflection, which brought a greater educational value than literature classes in secondary school. Moreover, the comments that were given during the clips added a touch of magic to the scenes (and the movies in total) by showing us the existence of the messages beneath the surface of the movies".

"It seems that the goal is also to affect the behavior of the student when he is confronted with a choice. But the session is not showing which direction is best to follow. It is only stimulating the student to take an active decision for himself when confronted with a choice, not to forget where he stands for, and to be aware of the underlying meanings of different options."

Participants quickly grasped that the purpose of the film-clip methodology was not only to evoke emotions but to help the audience reflect on them and figure out how to translate what they learn into attitudes and action. Reflection is the necessary bridge to move from emotions to behavior. The audience comes to the session to learn a "technique" but the bottom line is that they are touched by the experience in ways that both incorporate and transcend medicine.

\subsection{What about Appraisal? Which are the Evidences of Succeeding? How Can We be Sure This Is Working?}

The academic community requests proof of the effectiveness of a new technique before advocating or even supporting its widespread application. Educators have long ago learned that the measurement of success in teaching remains an elusive, controversial, and at the least quite ambiguous goal. We should not confuse quality teaching with successful teaching, one that produces learning as is understood exclusively in its achievement sense (Colt H, Quadrelli S \& Friedman L, 2011). At this point, we can envision why those "intangibles" topics, difficult to teach and to assess, in which ethics, empathy, compassion and commitment are included, could be endorsed through the cinema education methodology. What we can say is that acquiring a taste for the aesthetic provides an additional dimension to medical learning. Maybe, in Pascal's words, this has something to do with those "reasons from the heart, those reasons that our mind is not able to understand". Some quotes coming from the participants endorse this issue (Blasco, Moreto, Roncoletta, Levites \& Janaudis, 2006), (Blasco, Mônaco, Benedetto, Moreto \& Levites, 2010).

I took up this work [medicine] because I liked it. Projects like this [the movie clip teaching] are necessary to prevent one from losing touch with the real world. With these themes one questions not only medicine but also the human being. Physicians care for something special, [because they are] obliged to treat people. If I were unable to deal with a patient, to convince him, I would be helpless.

The movies, the music, the comments, all together is a pleasant experience and goes deep into your life, and you realize you are not alone in all this complexity and in your own challenges. People accept their own emotions, there is a whole disclosure among the audience, and emotional barriers are overcome. It doesn't matter if this is academic or not; it works for lifting up people.

As our ability to assess the "intangibles" in medical practice progresses, we will be better able to document the value of this and other humanities-based methodologies, both in terms of effects on students' personal lives and on their interactions with patients.

\section{Practical Guides for Using Movies to Nurture Empathy}

Because of the soft edges of empathy, and because empathy is more related to the response we expect from the audience rather than something we are putting in them, making a list of empathetic films is quite a challenge. All we can do is to grasp a group of movies-mostly scenes for building clips- that in our experience have evoked empathic reactions in the audience.

In keeping with our methodology, scenes are described followed by examples of the educator's responses while the clip is playing are shown. In some scenes, no responses are offered and educators are encouraged to articulate their own responses. (See Tables 1 to 5)

You can try this, and see what happens. And, be aware: if the learners suggest some other scenes, from their own 
viewing, as a kind of answer you can be sure there is an empathic climax going on and the methodology is working indeed.

Table 1. Listening

\begin{tabular}{cl}
$\begin{array}{c}\text { Movie } \\
\text { (Scene and Time Counting) }\end{array}$ & \multicolumn{1}{c}{ Topics and Comments } \\
\hline The Spitfire Grill & $\begin{array}{l}\text { Percy tells her tragic story (rape, miscarriage), her friend just listens } \\
\text { and at the end places her hand on Percy's shoulder without saying a } \\
\text { word. How we need to listen to peoples' stories, with kind } \\
\text { watchfulness. Are we able to just listen to the patients' stories without } \\
\text { interrupting? How long? }\end{array}$ \\
\hline $\begin{array}{c}\text { (01:31:36- 01:35:05) } \\
\text { (1:36:00 - 1:37:30) }\end{array}$ & $\begin{array}{l}\text { The murderer is about to be executed. The nun listens to his story with } \\
\text { a watchful attitude: I don't know what love is. I have never been loved. }\end{array}$ \\
$\begin{array}{l}\text { I need to die to discover what love is. Just listening to him, showing } \\
\text { full understanding. Listening is a kind of wonderful endurance and }\end{array}$ \\
support.
\end{tabular}


Table 2. Who are they? Understanding people

Movie

(Scene and Time Counting)

The Legend of 1900

(0:50:00 - 0:52:40)

(1:03:00-1:04:35)

(1:56:51- 1: 58:35)

Nurse Betty

(1: 40:30- 1: 41:25)
Topics and Comments

In this scene the pianist explains to his friend the origin of his inspiration: observing people. His music does not come from the music schedule but from the people he observes.

Doctoring is all about a creative art. Do we care about schedules and guidelines, even about the right diagnosis, before observing carefully patients' needs, their stories, and realizing who they are?

What is their story? You know they are Africans. But you don't know their story. You are not just a man from Georgia. You are an ex-slave and now devoted to the cause of abolition slavery. This is your story. So, you need to know their story.

Maybe, by putting a quick diagnosis on the patient -even correct- the physician is led to miss the patient's whole story. Are we really intrigued by the patient's story?

This is an outstanding scene. The young boy has become a guerrilla fighter who he doesn't recognize his father, even his own roots and family. In this scene, the boy's father faces his own son pointing an arm toward him, and slowly starts reminding him about family, about good memories, showing compassion and understanding for the devilish process in which the young boy has been immersed. "You are good boy, who loves soccer and school. Your mother loves you so much. She waits by the fire making plantains with your sister. And the new baby The cows wait for you, and Babu, the wild dogs who minds no one but you. I know they made you do bad things, but you are not a bad boy. I am your father who loves you, and you will come home with me and be my boy again"

Morgan Freeman talks to Renée Zellweger fostering confidence in her. You don't need that doctor. You don't need any man. You know why? Because you've got yourself.

One of the great challenges in doctoring is to help patients and people look inside, reflect and find who they really are. Helping people be rid of self-delusion is immensely therapeutic, a process which requires expertise and previous understanding of the human being with whom we are dealing. 
Table 3. Meeting people's needs

\begin{tabular}{|c|c|}
\hline $\begin{array}{c}\text { Movie } \\
\text { (Scene and Time Counting)) }\end{array}$ & Topics and Comments \\
\hline $\begin{array}{c}\text { Marvin's Room } \\
(1: 33: 00 \text { - 1:34:00) }\end{array}$ & $\begin{array}{l}\text { In this wonderful scene, Lee (Meryl Streep) realizes the meaning of } \\
\text { caring. Bessie (Diane Keaton) calms down her ill father Marvin while } \\
\text { playing with a little mirror. To care implies, very often, not only } \\
\text { technical support but mainly an absolute dedication. }\end{array}$ \\
\hline $\begin{array}{c}\text { Patch Adams } \\
(0: 12: 33-0: 16: 30)\end{array}$ & $\begin{array}{l}\text { Patch helps patients to shoot "imaginary squirrels" during night time. } \\
\text { After that, he realizes that his time in the hospital is done, realizing } \\
\text { that what he wants to do is to help people by using his gift of } \\
\text { knowing how to talk to them. }\end{array}$ \\
\hline$(1: 35: 31-1: 36: 28)$ & $\begin{array}{l}\text { In this pasta swimming-pool scene, Patch finds a way to help one } \\
\text { patient self-nourish. }\end{array}$ \\
\hline $\begin{array}{l}\text { A Beautiful Mind } \\
(1: 43: 42-1: 45: 15)\end{array}$ & $\begin{array}{l}\text { Alicia explains to her husband, John Nash, what is real through } \\
\text { touching him and letting him to touch her face and heart. "Do you want, } \\
\text { to know what is real? This is real. Maybe the answer is not in here..." } \\
\text { (in the brain) "but in here..." (touching his heart). }\end{array}$ \\
\hline $\begin{array}{c}\text { Analyze This } \\
(0: 19: 50-0: 22: 30)\end{array}$ & $\begin{array}{l}\text { Robert De Niro plays a Mafia Godfather. He visits a psychiatrist, and } \\
\text { tells a story of a friend of him with psychological troubles. Billy } \\
\text { Crystal, the psychiatrist, realizes that the Mafia boss is talking about } \\
\text { himself, and takes the risk of pointing this out. The results are fantastic, } \\
\text { and he gains the gangster's confidence and compliance. }\end{array}$ \\
\hline & $\begin{array}{l}\text { Give me one reason to not kill myself. I will give you two: You dance } \\
\text { tango and drive a Ferrari as no one else. Maybe those are not great } \\
\text { reasons to live, neither providing deep meaning for someone's life. But } \\
\text { at this point it is what really works to keep Al Pacino alive. }\end{array}$ \\
\hline $\begin{array}{l}\text { Scent of a Woman } \\
(2: 00: 00-2: 00: 39)\end{array}$ & $\begin{array}{l}\text { You can complete this scene, going back in the movie to the Ferrari } \\
\text { scene }(1: 42: 30-1: 43: 10) \text { and the Tango scene }(1: 26: 00-1: 27: 15) \text { and } \\
\text { put it all together in a clip. The result is inspiring. }\end{array}$ \\
\hline $\begin{array}{c}\text { Limelight } \\
(0: 59: 28-1: 00: 43)\end{array}$ & $\begin{array}{l}\text { This scene in Chaplin's classic movie points out the superb results you } \\
\text { can get when instead of focusing on your own problems, you care } \\
\text { about people. This is how Teresa recovers from her illness because she } \\
\text { is worried about Calvero who is depressed, and tries to help him. }\end{array}$ \\
\hline
\end{tabular}


Table 4. Understanding other one's suffering

Movie

(Scene and Time Counting)

\section{Topics and Comments}

Joy Gresham asks C.S.Lewis what will happen to him when she has died. She has Ewing Sarcoma, and the end is quite close. Lewis avoid the topic, but Joy insists: "The pain you will feel then, is part of the happiness you are feeling right now”.

To understand other's suffering implies a broad perspective in which happiness and suffering are mixed together in life. Maybe this scene can bring some inspiration to brighten people's suffering.

Bob Jones (Michael Keaton) has a terminal disease. The attending doctor says there is nothing more that could be done. Bob gets out of the office but suddenly he comes back: You took away my hope. This is the only thing I still have and you have no right to deprive it.

My Life

(0:20:50 - 0:22:40)

(0:23:10:00-0:23:40)

Telling bad news: how you can be honest, and at the same time keep hope alive. How can we deal with other's suffering without depressing them?

Look at me. I will be the face of love for you while they do it. To be the face of love is the essence of sharing suffering and supporting those who are in pain. How can we perform the face of love when seeing patients?

(1: 41:49- 1:42:09)

Daniel Day Lewis is imprisoned along with his father. The young man thinks his father is weak and pusillanimous and argues with him. At this moment his father calms him down with kind gestures since he realizes his son's suffering. What actually calms people down is kindness and tenderness.

Today, I saw myself through your eyes and I am sorry. This couple (Bruce Willis and Michelle Pfeiffer) has frequent arguments. But they reflect and find their own responsibilities instead of blaming each other.

It is cruel to see you cry and I cannot. This terrible pain I cannot express. Does every human being that I care for just leave?

Bicentennial Man

(1: $24: 40-1: 25: 20)$

Understanding other's suffering sometimes implies a willingness to share, and even demonstrate, it. Is it indeed possible to share without expressing those feelings?

Edith Piaf is depressed and has already given up singing. Her friends don't know how to encourage her. In this context, a young composer brings her a new song: Rien de rien, that is I don't regret of anything I did in my life. The music cheers up Edith: "I love this. This is me, you grasped my entire life. The scene portrays how little things well adapted to those who are suffering can make a tremendous difference. In the next

scene, Edith is singing again on the stage (2: 07:15-2:09:19)

\section{La Mome (The story of singer Edith Piaf)}

(1:52:00- 1:54: 21) 
Table 5. Empathy on command: teachers and leaders

\begin{tabular}{|c|c|}
\hline $\begin{array}{c}\text { Movie } \\
\text { (Scene and Time Counting) }\end{array}$ & Topics and Comments \\
\hline $\begin{array}{l}\text { Searching for Bobby Fischer } \\
\qquad(0: 35: 00-0: 37: 00)\end{array}$ & $\begin{array}{l}\text { The chess master asks the boy to think about the next four moves } \\
\text { without moving the pieces. I can think without moving them. And the } \\
\text { master: I will make it easier for you ( the teacher throws the chess pieces } \\
\text { down to the floor, clearing the chessboard) }\end{array}$ \\
\hline $\begin{array}{l}\text { Music of the Heart } \\
(0: 28: 00-0: 29: 00) \\
(1: 48: 00-1: 49: 00)\end{array}$ & $\begin{array}{l}\text { The violin teacher helps the little disabled girl. She can stand up for } \\
\text { playing violin. What really matters is to get strength inside. } \\
\text { Don't look at the audience, look at me. And play from the heart. Those } \\
\text { are the encouraging words to the young members of the violin orchestra } \\
\text { before the performance. }\end{array}$ \\
\hline $\begin{array}{l}\text { Mr Holland's Opus } \\
\text { (0:33:28- 0:34:39) }\end{array}$ & $\begin{array}{l}\text { The girl can't play the clarinet properly. She is worried and can't } \\
\text { succeed. Mr. Holland finds the right advice for getting her relax and } \\
\text { allowing a good performance: Just play the sunset! }\end{array}$ \\
\hline $\begin{array}{c}\text { Men of Honor } \\
(1: 57: 21-1: 59: 37)\end{array}$ & $\begin{array}{l}\text { The disabled man is required to walk twelve steps to prove he can be a } \\
\text { navy diver. He performs the task because of the great mentoring of his } \\
\text { coach. Mentoring is essential to bring out the best in people. }\end{array}$ \\
\hline $\begin{array}{l}\text { We were soldiers } \\
(0: 34: 00-0: 35: 00)\end{array}$ & $\begin{array}{l}\text { I will be the first to set foot on the battle and the last to step off. I will } \\
\text { leave no one behind. The story of the Lt. Col. Hal Moore and his } \\
\text { leadership in the Vietnam War }\end{array}$ \\
\hline $\begin{array}{l}\text { Spartacus } \\
\text { II Part (0:49:30 - 0:50:50) }\end{array}$ & $\begin{array}{l}\text { This is a great scene of Kubrick's classic movie about empathy in a } \\
\text { team. Slaves you were, and slaves you remain. But you will be spared of } \\
\text { the terrible penalty of the crucifixion at the single condition that you } \\
\text { identify the body or the living person of the slave called Spartacus. And } \\
\text { then, here and there, men stand up shouting I am Spartacus, I am } \\
\text { Spartacus. Everyone is Spartacus. More than a person, it is an idea }\end{array}$ \\
\hline $\begin{array}{l}\text { K-19 The Widowmaker } \\
\qquad(1: 45: 30-1: 47: 45)\end{array}$ & $\begin{array}{l}\text { The soviet nuclear submarine is in a great trouble. The Captain has to } \\
\text { decide how to save the boat and prevent a nuclear disaster. At this point, } \\
\text { one of the officers (Liam Neeson) gives a different suggestion to engage } \\
\text { all the crew: Don't give orders to the men. Just ask them. The captain } \\
\text { explains the situation and stands by waiting for the responses. And they } \\
\text { come, one by one, addressing the consensus and the strength of team } \\
\text { work. }\end{array}$ \\
\hline $\begin{array}{l}\text { Her Majesty, Mrs. Brown- } \\
\quad(1: 06: 10-1: 08: 20)\end{array}$ & $\begin{array}{l}\text { Empathy and leadership often come from those who, theoretically are } \\
\text { not in command. This is an elegant movie about Queen Victoria's } \\
\text { horseman and how he helps the Queen to recover from depression after } \\
\text { the death of Prince Albert. In this scene the servant asks to resign his } \\
\text { duty, but the Queen forbids him. I need you to be what I must be. } \\
\text { Without you I cannot find the strength to accomplish my obligations. }\end{array}$ \\
\hline The King's Speech & $\begin{array}{l}\text { The story of George VI and his fight against stammering, helped by the } \\
\text { speech therapist who is a real teacher and leader back stage. }\end{array}$ \\
\hline$(1: 23: 46-1: 28: 10)$ & $\begin{array}{l}\text { The king is told that the therapist has no credit, or qualifications. I have } \\
\text { the experience. I helped those boys who came from the War, and that } \\
\text { War was a real experience. In this scene, the therapist provokes the } \\
\text { King and gets from him the best response: a strong voice! }\end{array}$ \\
\hline$(1: 42: 20-1: 48: 15)$ & $\begin{array}{l}\text { This is a remarkable scene, the King's Speech, framed by the } \\
\text { Beethoven's Seventh Symphony (Second Movement). The King talks } \\
\text { through the radio microphone to all the country, and overseas, while } \\
\text { the therapist is "conducting" the speech and, seemingly, the Symphony } \\
\text { at the same time. A touching scene with a high empathic score. }\end{array}$ \\
\hline
\end{tabular}


In this session, the list of scenes provided have a common ground: How empathy is useful for those in command of others. Empathetic teachers and leader are real facilitators. They push people they lead to perform their best. And they are always inspiring role models. We can find multiple examples in the movies. Those scenes below are some of our favorites: we have used them several times and they score high in their empathy impact.

\section{References}

Aderman, D., \& Berkowitz, L. (1983). Self-concern and the unwillingness to be helpful. Soc Psychol Q, 46, 293-301. http://dx.doi.org/10.2307/3033717

Bauer, J. (2005). Warum ich fu" hle, was Du fu" hlst. Intuitive Kommunikation und dasGeheimnis der Spiegelneurone (Why I feel what you feel. Intuitive communication and the mystery of the mirror neurons). Hamburg: Hoffmann und Campe.

Berger, J., \& Mohr, J. (1967). A Fortunate Man: The history of a country Doctor. London. The Penguin Press.

Blasco, P. G. (2001). Literature and Movies for Medical Students. Family Medicine, 33(6), 426-8. Retrieved from http://www.sobramfa.com.br/en/pagina.php?p=articles\&a $=11$

Blasco, P. G. (2002). Medicina de Família \& Cinema: Recursos Humanísticos na Educação Médica. São Paulo: Ed. Casa do Psicólogo.

Blasco, P. G., Moreto G., Roncoletta, AFT, Levites, M. R., \& Janaudis, M. A. (2006). Using movie clips to foster learners' reflection: Improving Education in the Affective Domain. Fam Med, 38(2), 94-6. Retrieved from http://www.sobramfa.com.br/en/pagina.php? $\mathrm{p}=$ articles\& $\mathrm{a}=15$

Blasco, P. G., Roncoletta, AFT, Moreto, G., Levites, M. R., \& Janaudis, M. A. (2006). Accompanying Physicians in Their Family Practice: A Primary Care Model for Medical Students' Learning in Brazil. Fam Med, 38(9), 619-621. http://www.sobramfa.com.br/en/pagina.php?p=articles\&a $=6$

Blasco, P. G., Pinheiro, TRP, Ulloa-Rodriguez, M., \& Angulo-Calderón, N. (2009). El Cine en la Formación Ética del Medico: Un recurso pedagógico que facilita el aprendizaje. Persona y Bioética, 13, $114-127$. http://www.sobramfa.com.br/pagina.php? $\mathrm{p}=$ artigos \& $\mathrm{a}=49$

Blasco, P. G., Benedetto, MAC, Garcia, DSO, Moreto, G., Roncoletta, AFT, \& Troll, T. (2010). Cinema for educating global doctors: from emotions to reflection, approaching the complexity of the Human Being. Primary Care, 10, 45-47. Retrieved from http://www.sobramfa.com.br/en/pagina.php? $\mathrm{p}=$ articles\&a $=48$

Blasco, P. G., Mônaco, C.F., Benedetto, MAC, Moreto, G., \& Levites, M. R. (2010). Teaching Through Movies in a Multicultural Scenario: Overcoming Cultural Barriers through emotions and reflection. Fam Med, 42 (1), 22-24. Retrieved from http://www.sobramfa.com.br/en/pagina.php? $\mathrm{p}=\operatorname{articles} \& \mathrm{a}=46$

Blasco, P. G. (2011 a). Humanizando a Medicina: Uma Metodologia com o Cinema. Centro Universitário São Camilo. São Paulo.

Blasco, P. G. (2011 b). Review of Henri Colt, Silvia Quadrelli, and Lester Friedman, eds., The Picture of Health: Medical Ethics and the Movies: Getting Familiar with the Cinema Education Methodology. American $\begin{array}{lllll}\text { Journal of } \quad \text { Bioethics, } & \text { 39-41. } & \text { Retrieved } & \text { from }\end{array}$ http://www.sobramfa.com.br/en/pagina.php? $\mathrm{p}=\operatorname{articles} \& \mathrm{a}=83$

Blasco, P. G., González-Blasco, M., Levites, M. R., Moreto, G., \& Tysinger, J. W. (2011). Educating through Movies: How Hollywood Fosters Reflection. Creative Education, 2, 174-180. http://dx.doi.org/10.4236/ce.2011.23024

Colt, H., Quadrelli, S., \& Friedman, L. (Eds.). (2011). The Picture of Health. Oxford University Press. New York.

Decety, J., \& Jackson, P. (2006). A social-neurosience perspective on empathy. Curr Dir Psychol Sci, 15, 54-8. http://dx.doi.org/10.1111/j.0963-7214.2006.00406.x

Decety, J., \& Jackson, P. L. (2004). The functional architecture of human empathy. Behav Cogn Neurosci Rev, 3 , 71-100. http://dx.doi.org/10.1177/1534582304267187

Gallese, V. (2003). The roots of empathy: the shared manifold hypothesis and the neural basis of inter subjectivity. Psychopathology, 36, 171-80. http://dx.doi.org/10.1159/000072786

González-Blasco, M., Levites, M. R., Moreto, G., \& Blasco, P. G. (2010). Cinema y Educación. Cómo mejorar 
las habilidades pedagógicas de los profesores y fomentar la reflexión de profesores y alumnos. Arch Med Fam, 12, 137-149. Retrieved from http://www.sobramfa.com.br/pagina.php?p=artigos\&a=57

Hojat, M., Gonnella, J. S., Mangione, S., Nasca, T. J., \& Magee, M. (2003). Physician empathy in medical education and practice: experience with the Jefferson scale of physician empathy. Semin Integr Med, 1, 25-41. http://dx.doi.org/10.1016/S1543-1150(03)00002-4

Hojat, M. (2007). Empathy in Patient Care. Antecedents, Development, Measurement, and Outcomes. New York, NY: Springer.

Hojat, M., Vergare, M. J., Maxwell, K., Brainard, G., Herrine, S. K., Isenberg, G. A., Veloski, J., \& Gonnella, J. (2009). The Devil is in the Third Year: A Longitudinal Study of Erosion of Empathy in Medical School. Acad Med, 84, 1182-1191. http://dx.doi.org/10.1097/ACM.0b013e3181b17e55

Kohler, W. (1929). Gestalt psychology. Oxford: Liveright.

Larson, E. B., \& Yao, X. (2005). Clinical Empathy as emotional Labor in the Patient-Physician Relationship. JAMA, 293(9), 1100-1106. http://dx.doi.org/10.1001/jama.293.9.1100

Mead, G. H. (1934). Mind, self, and society. Chicago: University of Chicago Press.

Neumann, M., Bensing, J., Mercer, S., Ernstmann, N., Ommen, N., \& Pfaff, H. (2009). Analyzing the "nature" and "specific effectiveness" of clinical empathy: A theoretical overview and contribution towards a theory-based research agenda. Patient Education and Counseling, 74, 339-346 http://dx.doi.org/10.1016/j.pec.2008.11.013

Piaget, J. (1932). The moral judgment of the child. London: Kegan, Paul, Trench, Trubner.

Rizzolatti, G., \& Sinigaglia, C. (2006). So quell che fai:il cervello che agisce e I neuroni specchio. Milano. R Cortina ed.

Sade, R., Stroud, M., Levine, J., \& Fleming, G. (1985). Criteria for Selection of Future Physicians. Annals of Surgery, 201, 225-230. http://dx.doi.org/10.1097/00000658-198502000-00015

Shapiro, J. (2011). Movies help us explore relational ethics in health care. In Colt H, Quadrelli S \& Friedman L (Eds). The Picture of Health. (pp.19-28). Oxford University Press. New York.

Stephan, W. G., \& Finlay, K. A. (1999). The role of empathy in improving inter- group relations. J Soc Issues, 55, 729-743. http://dx.doi.org/10.1111/0022-4537.00144

Wicker, B., Keysers, C., Plailly, J., Royet, J. P., Gallese, V., \& Rizzolatti, G. (2003). Both of us are disgusted in my insula: the common neural basis of seeing and seeking disgust. Neuron, 40, 644-55. http://dx.doi.org/10.1016/S0896-6273(03)00679-2 